\title{
Diversity and antimicrobial potential of endophytic fungi from aromatic plants of Bhadra Wildlife Sanctuary, Western Ghats, Karnataka
}

\author{
Rajeshwari Jagadish (D), Srinivas Chowdappa* \\ Fungal Metabolites and Plant Pathology Research Laboratory, Department of Microbiology and Biotechnology, Bangalore University, Bangalore, India.
}

\begin{tabular}{l}
\hline ARTICLE INFO \\
\hline Article history: \\
Received on: October 21, 2020 \\
Accepted on: March 05, 2021 \\
Available online: September 01, 2021 \\
\hline
\end{tabular}

Key words:

Endophytic fungi, aromatic plants, Baba Budangiri, Lakkavalli, Mullayanagiri, antimicrobial activity

\begin{abstract}
Endophytic fungi are the main sources of novel bioactive compounds because of their unique inhabitation ability. This work focus on studying the diversity of fungal endophytes from eleven aromatic plants in three locations of Bhadra Wildlife Sanctuary i.e. Baba Budangiri, Lakkavalli, Mullayanagiri and screened for antimicrobial potential. Three hundred and forty-three endophytic fungi were isolated, and the highest colonization frequency was in Plectranthus amboinicus (60\%) collected from the Baba Budangiri region. Fusarium sp., was the most prominent genus isolated from all plant samples. The relative density (RD) of isolates varied within plant parts, with leaf fragments of the Baba Budangiri region having the highest RD 42\% and root segments showed the least RD value from all three locations. The Shannon- Wiener and species richness was highest in the Lakkavalli region. The Jaccard's similarity indices of fungal endophytes compared between the three sites ranged from 0.33-0.38. The antimicrobial activity showed that the endophyte Chaetomium globosum had maximum inhibition of $22 \mathrm{~mm}$ against Escherichia coli and Bacillus subtilis. Also, a wide range of antifungal activity was exhibited by $C$. globosum, inhibiting the radial growth of Fusarium oxysporum by $74.5 \%$. C. globosum can be further exploited for the production of bioactive compounds.
\end{abstract}

\section{INTRODUCTION}

Microorganisms are important forms of life, occupying virtually every possible niche on earth [1]. It has been estimated that, including endophytic fungi, there are 5 million different fungal species on our planet [2]. Endophytic fungi are those organisms that reside within plant tissues throughout their life cycle without causing any symptoms of a disease [3]. De Bary first introduced the term "endophyte" in 1866, where "endon" means inside and "phyton" means plant [4]. There exists a symbiotic relationship between the plant and the endophytic fungi, where the plant provides nutrients to the microbe [5]. In turn, the microbe produces secondary metabolites that guard the host plant against many external factors like an attack by animals, insects, microbes and

\footnotetext{
*Corresponding Author

Srinivas Chowdappa, Fungal Metabolites and Plant Pathology Research Laboratory, Department of Microbiology and Biotechnology, Bangalore University, Bangalore, India. E-mail: srinivasbub@gmail.com
}

drought, nutrient depletion in soil, etc. [6,3]. It is reported that some endophytes have evolved the ability to produce metabolites similar to their host plant, which may be due to co-evolution or genetic transfer between the endophyte and the plant [7]. Such a mutual interrelationship between endophytic fungi and their host plants can induce the latter to produce active metabolites, which can be used in pharmaceuticals and agriculture [8,9]. The origin, sustenance level, and ecological niche of the host plants are considered during isolation of endophytic fungi [10]. The Western Ghats being older than the Himalayan Mountains represents a unique ecosystem [11]. Its diverse topography and environmental conditions are the reasons for the rich floral diversity it possesses, which includes a wide variety of aromatic plant species [12]. Bhadra Wildlife Sanctuary, which is situated amid the Western Ghats region, is enclosed by Mullaianagiri, Baba Budangiri, Gangegiri, and Hebbegiri hills, and the river Bhadra flows through it [13]. The sanctuary is covered with moist deciduous, dry deciduous, evergreen, semi-evergreen, scrub, plantations, and grassland [14]. 
Table 1. Location and climatic conditions of the sample site in Bhadra Wildlife Sanctuary.

\begin{tabular}{lccc}
\multicolumn{1}{c}{ Description } & Collection site & Lakkavalli & Mullayanagiri \\
Coordinates & $13.284134^{\circ} \mathrm{N}$ & $13^{\circ} 22^{\prime}$ to $13^{\circ} 47^{\prime} \mathrm{N} 75^{\circ} 29^{\prime}$ to $75^{\circ} 45^{\prime} \mathrm{E}$ & $13^{\circ} 23^{\prime} 27.5^{\prime \prime} \mathrm{N}$ \\
& $75.997893^{\circ} \mathrm{E}$ & & $75^{\circ} 43^{\prime} 17^{\prime \prime} \mathrm{E}$ \\
Elevation & $843 \mathrm{~m}(2,766 \mathrm{ft})$ & $300 \mathrm{~m}(1,000 \mathrm{ft})$ & $1,925 \mathrm{~m}(6,316 \mathrm{ft})$ \\
Annual rainfall & $100-150 \mathrm{~cm}$ & $120-260 \mathrm{~cm}$ & $150-200 \mathrm{~cm}$ \\
Temperature & $20^{\circ} \mathrm{C}-25^{\circ} \mathrm{C}$ & $19^{\circ} \mathrm{C}-35^{\circ} \mathrm{C}$ & $20^{\circ} \mathrm{C}-25^{\circ} \mathrm{C}$ \\
\hline Source: $[19-21]$. & & &
\end{tabular}

The relative abundance (RA) of each genus was also calculated by using the following formula [27]:

$\mathrm{RA}=\frac{\text { Number of isolates belonging to a particular species }}{\text { Total number of endophytic fungi isolated }} \times 100$

The relative percentage of occurrence (RPO $\%$ ) of different fungi groups was calculated using the following formula [28]:

RPO $(\%)=\frac{\text { Number of isolates from particular fungal genera }}{\text { Total number of isolates of all the fungal genera }} \times 100$

Camargo's index was used to determine dominant endophytic fungi among the isolates. A species is defined as dominant when it satisfies RA $>1 / S$, where " $S$ " is species richness. RA $=f / n$, where, " $f$ " is the number of times the isolate occurred and " $n$ " is the total isolates [29].

Shannon-Weiner diversity and Simpson's diversity indices, species richness, and evenness were determined using the following formula and the data were analyzed as follows [30]:

Shannon-Weiner diversity index $(H)=\Sigma(\mathrm{Pi})(\mathrm{In} \mathrm{Pi})$

where $\mathrm{Pi}$ is the RA of species $(\mathrm{Pi}=n / N)$ and $\mathrm{In} \mathrm{Pi}$ is the natural $\log$ of $\mathrm{Pi}$ value to the base 2 .

$$
\text { Simpson's Diversity index (D) }=1-\frac{\sum n(n-1)}{N(N-1)}
$$

Gini Simpson's Diversity $=1-\sum_{i}\left(\mathrm{n}_{i} / N\right)^{2}[31]$.

where $N$ is the total number of isolates and $n$ is number of individuals belonging to a particular species.

Species evenness $(E)$ and was calculated using the following formula: $E=H^{\prime} / \ln S$ [32].

Species richness $=S / H^{\prime} N$, where $S=$ the total number of species [32].

\subsection{Jaccard's Similarity Index (JI)}

To measure the range of similarity of fungal endophytes shared between the three sample sites, JI was analyzed using the following formula:

$$
\mathrm{JI}=a(b+c)-a
$$

where $a$ represents the number of species isolated in any two sample sites, $b$ is the number of species present only in location 1 , and $c$ is the number of species present only in location 2. JI ranges from 0 to 1 , where 0 signifies no overlap or no taxa shared and 1 signifies complete overlap or all taxa shared between the two sample sites analyzed [33].

\subsection{Antimicrobial Activity}

\subsubsection{Test Organisms}

The endophytic fungal isolates were screened for antibacterial activity against both Gram-positive and Gram-negative human pathogenic bacteria like Staphylococcus aureus (NCIM-2076), Bacillus subtilis (NCIM-5698), Escherichia coli (NCIM2065), Pseudomonas aeruginosa (NCIM-2036), and Klebsiella pneumoniae (NCIM-2706) [34]. Plant pathogenic fungi like Fusarium oxysporum (NCIM-1072), Alternaria alternate (NCIM718), and Aspergillus niger (NCIM-1004) were tested for antifungal activity. The test cultures were procured from National Collection of Industrial Microorganisms (NCIM) Pune, Maharashtra, India.

\subsubsection{Antibacterial Activity of Endophytic Fungi}

Antibacterial activity of endophytic fungi was carried out by agar plug assay. Each isolate was cultivated on PDA media at $30^{\circ} \mathrm{C}$ for 7 days. Then, disks were cut from the PDA plate (6 mm diameter) and transferred to the Mueller-Hinton agar media previously seeded with $1.5 \times 10^{5} \mathrm{CFU} / \mathrm{ml}$ of 24 -hours-old test bacteria Streptomycin $(30 \mu \mathrm{g} / \mathrm{ml})$ and sterile distilled water were loaded as positive control and negative control, respectively. The petri plates were refrigerated at $4^{\circ} \mathrm{C}$ for 8 hours for complete diffusion of antibacterial compounds present in the fungal disks and later incubated at $37^{\circ} \mathrm{C}$ for 12 hours. After incubation, the inhibition zone around the fungal disks was measured in millimeters using a scale [35].

\subsubsection{Antifungal Activity of Endophytic Fungi}

Antifungal activity of endophytic fungi was carried out by dual culture assay against three plant pathogens: A. alternata, $F$. oxysporum, and $A$. niger. Small plugs ( $3 \mathrm{~mm}$ in diameter) of test cultures were placed at one corner of the sterile PDA plate. On the same petri plate, a 7-day-old endophytic fungal culture was inoculated at the opposite end. The inoculated plates were kept at $27^{\circ} \mathrm{C}$ for $24-48$ hours. Test pathogens without the endophytes served as control plates. Filter paper disks inoculated with $10 \mu \mathrm{l}$ of fungicide Derosil plus ${ }^{\circledR}$ (with $10^{-1}$ dilution) and sterile distilled water were used as the positive and negative controls, respectively, and growth was regularly observed in both the petri plates. The 
inhibition percentage was calculated by using the following formula [36]:

$$
\text { Inhibition } \%=\frac{R-r}{R} \times 100
$$

where $R$ is the radius of the pathogen in control plate and $r$ is the radius of the pathogen with endophytic fungi.

The experiments for antimicrobial activity were carried out in triplicates and results are recorded in mean \pm standard deviation.

\section{RESULTS AND DISCUSSION}

\subsection{Isolation and Identification of Endophytic Fungi}

A total of 343 endophytic fungi were isolated from 11 aromatic plants including Cymbopogon citretus L., Mentha arvensis L., Ocimum basilicum L., Ocimum tenuiflorum L., Origanum majorana L., Oxalis corniculata L., Plectranthus amboinicus L., Rosmarinus officinalis L., Ruta graveolens L., Thymus vulgaris L., and Zingiber officinale L., which were collected from Baba Budangiri, Lakkavalli, and Mullayanagiri regions of Bhadra Wildlife Sanctuary (Table 2) (Fig. 2).

\subsubsection{Baba Budangiri}

Among the 343 isolates, 114 fungi representing 19 genera were found to be associated with plants collected from Baba Budangiri region. The highest CF was recorded in $P$. amboinicus with $60 \%$, followed by $O$. tenuiflorum (46\%). Amorphotheca sp., Bipolaris sp., Cladosporium sp., and F. oxysporum were some of the commonly occurring fungi in this region. O. majorana and $P$. amboinicus had the highest IR of 0.36 and $Z$. officinale showed the least IR of 0.15 . O. tenuiflorum exhibited maximum species richness of 13.52, followed by $M$. arvensis (12.52), and the minimum species richness was recorded in T. vulgaris (5.52). $P$. amboinicus harbored the maximum endophytic fungi among the 11 plants assessed with RA of 12.84. Camargo's index indicated that endophytic fungal species differed majorly between different plant samples, except for $M$. arvensis and $O$. tenuiflorum, which showed a similar Camargo's index of 0.07 (Table 3). F. solani and Cladosporium sp. were found to be the most dominant fungi to occur in this region (Fig. 3a).

\subsubsection{Lakkavalli}

A total of 118 isolates representing 25 different genera were found to be associated with plants from the Lakkavalli region. The highest $\mathrm{CF}$ was recorded in C. citretus (50\%), followed by $O$. basilicum (43.3\%). A. fumigatus, A. niger, C. clavata, $F$. circinatum, $F$. oxysporum, and Phomopsisi were some of the commonly occurring fungi in this region. P. amboinicus had the highest IR of 0.52 and $Z$. officinale showed the least IR of 0.2 . C. citretus exhibited maximum species richness of 14.51 , followed by $O$. basilicum (12.51) and minimum species richness was recorded in $Z$. officinale (3.5). C. citretus harbored the maximum endophytic fungi among the 11 plants assessed with an RA of 14.41. Carmargo's index ranged from 0.07 to 0.28 , with C. citretus having the minimum value of 0.07 (Table 3 ). Similar to Baba Budangiri region, F. solani, Cladosporium sp., and Cyindrocladium $\mathrm{sp}$. were found to be the most dominant fungi to occur in this region (Fig. 3b).

Table 2. List of selected aromatic plants collected from Bhadra Wildlife Sanctuary and its medicinal uses.

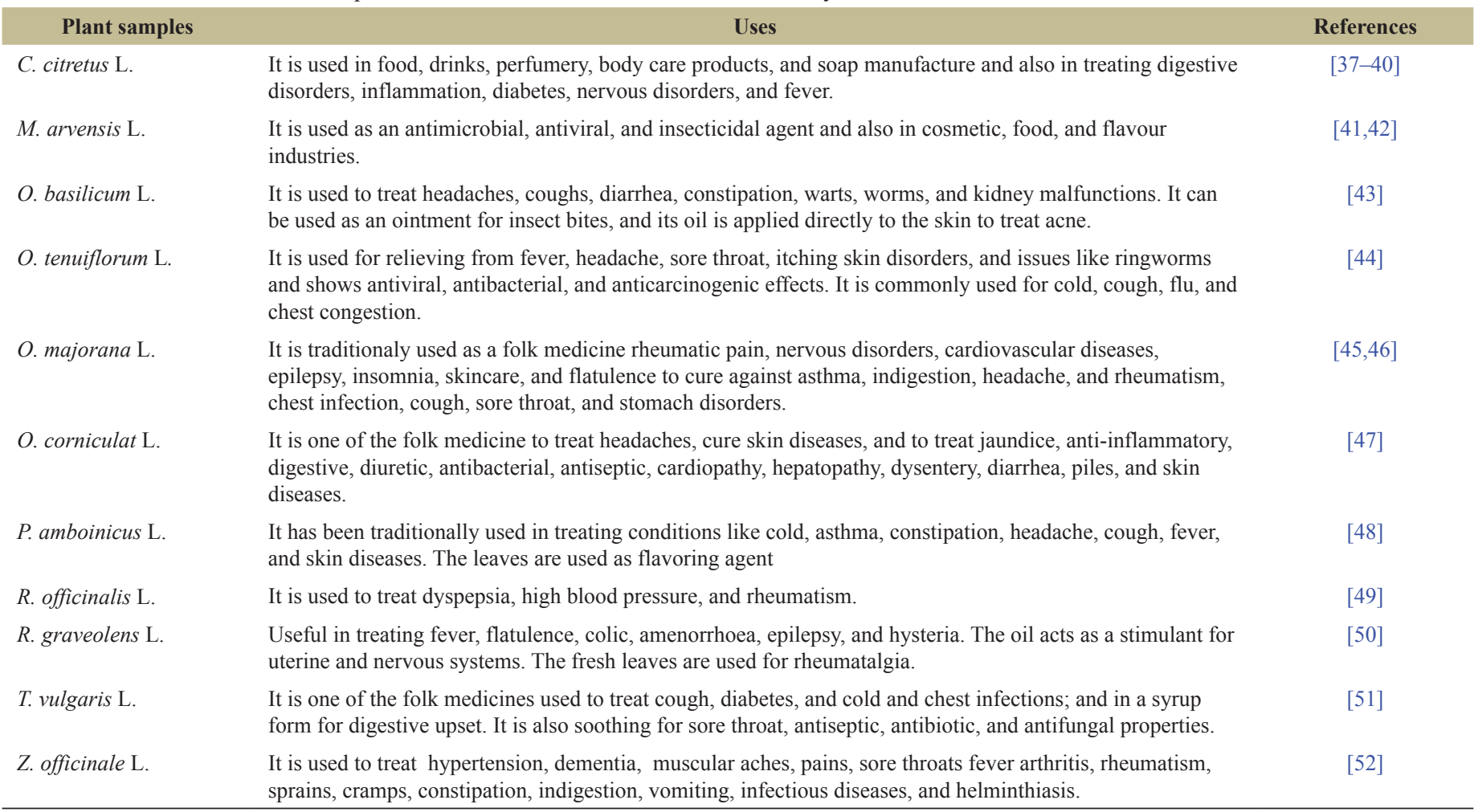



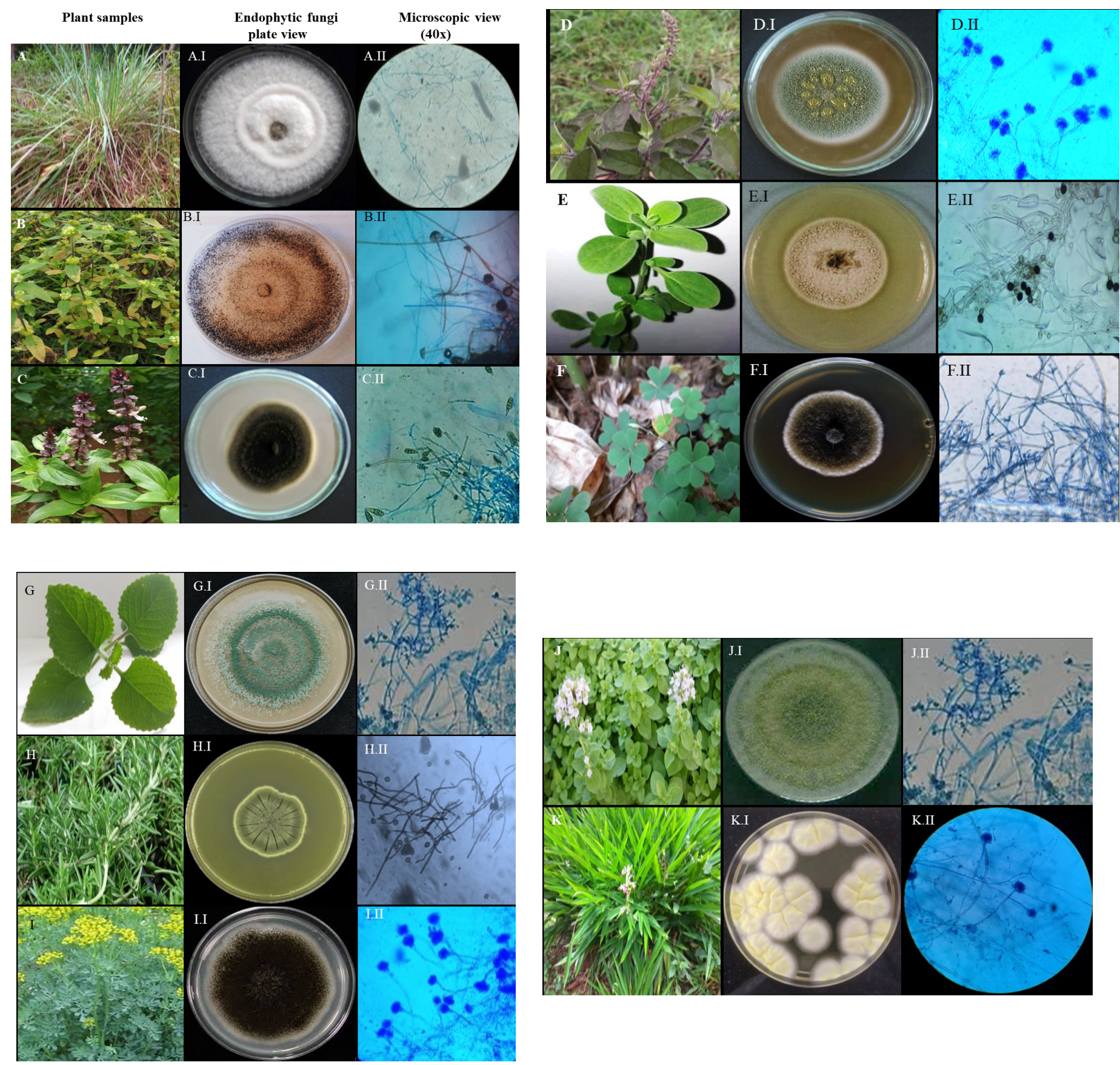

Figure 2. Aromatic plant samples collected from different locations of Bhadra Wildlife Sanctuary and endophytic fungi isolated (plate and microscopic view). A C.citretus L. and A.I F. oxysporum; B M. arvensis L. and B.I Rhyzopus sp.; C O. basilicum L. and C.I A. alternate; D O. tenuiflorum L. and D.I P. Crysogenum; E O. majorana L. and E.I Circinella sp.; F O. corniculata L. and F.I Cladosporium sp.; G P. amboinicus L. and G.I Tricoderma sp.; H R. officinalis L. and H.I Cladosporium sp.; I R. graveolens L. and I.I A. niger; J T. vulgaris L. and J.I T. viride; and K Z. officinale L. and K.I A. fumigatus.

\subsubsection{Mullayanagiri}

A total of 111 fungi representing 21 genera were found to be associated with plants from the Mullayanagiri region. The highest CF was recorded in O. tenuiflorum and P. amboinicus with $43.3 \%$, followed by $T$. vulgaris with $36.6 \%$ colonization. Amorphotheca sp. Cylindrocladium, F. solani, F. oxysporum, Penicillium sp., Pestalotiopsis, and Phoma sp. were identified as the commonly occurring fungi. $R$. officinalis had the highest IR of 0.48 and $Z$. officinale showed the least IR of 0.16. P. amboinicus exhibited maximum species richness of 12.2 , followed by $O$. tenuiflorum (11.42) and minimum species richness was recorded in $O$. majorana (6.51). P. amboinicus harbored the maximum endophytic fungi among the 11 plants assessed with RA of 12.51. Carmargo's index ranged from 0.08 to 0.15 , with $O$. tenuiflorum and $P$. amboinicus having the minimum value of 0.08 (Table 3 ). F. oxysporum and Penicillium sp. were found to occur dominantly in this region 


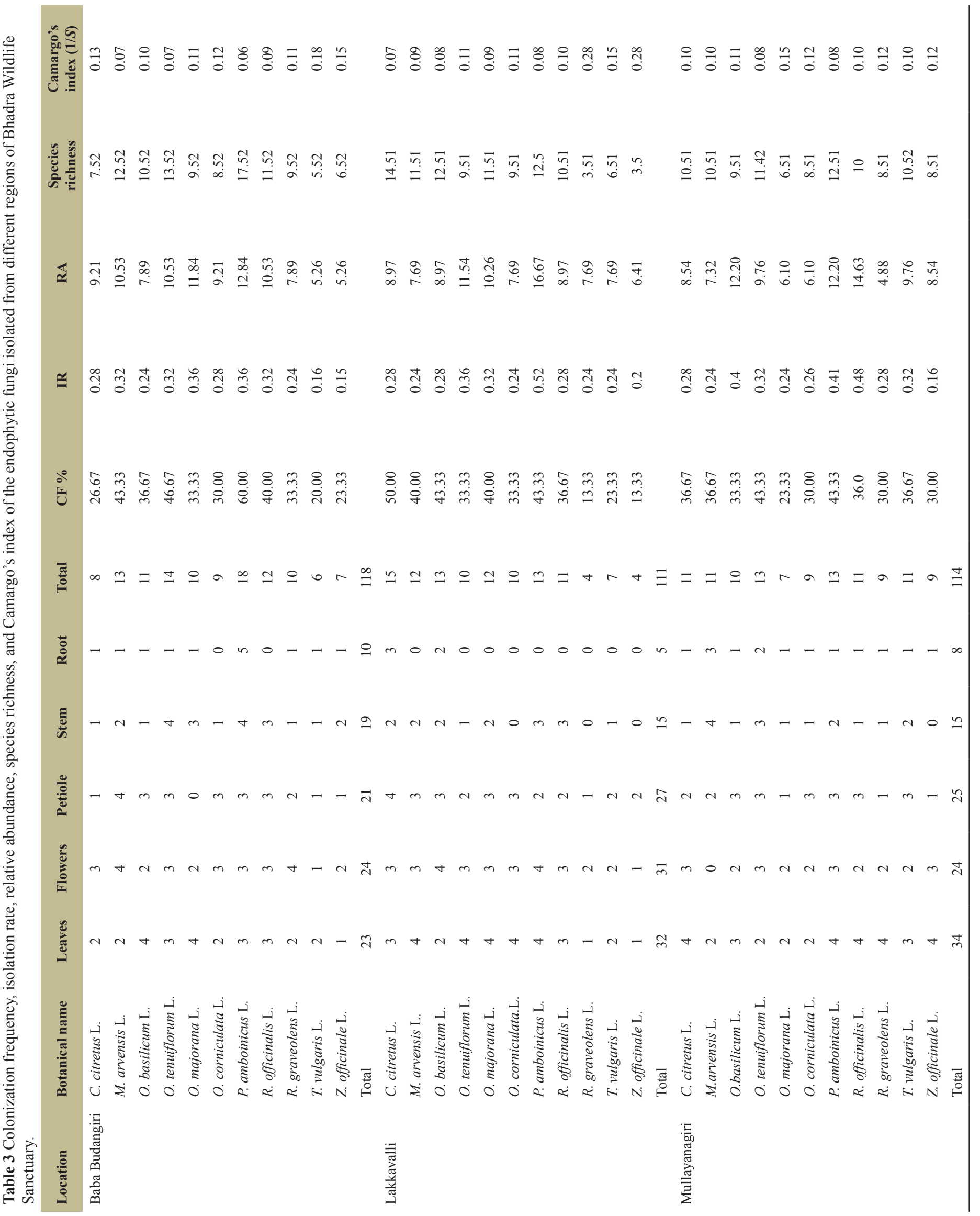


a
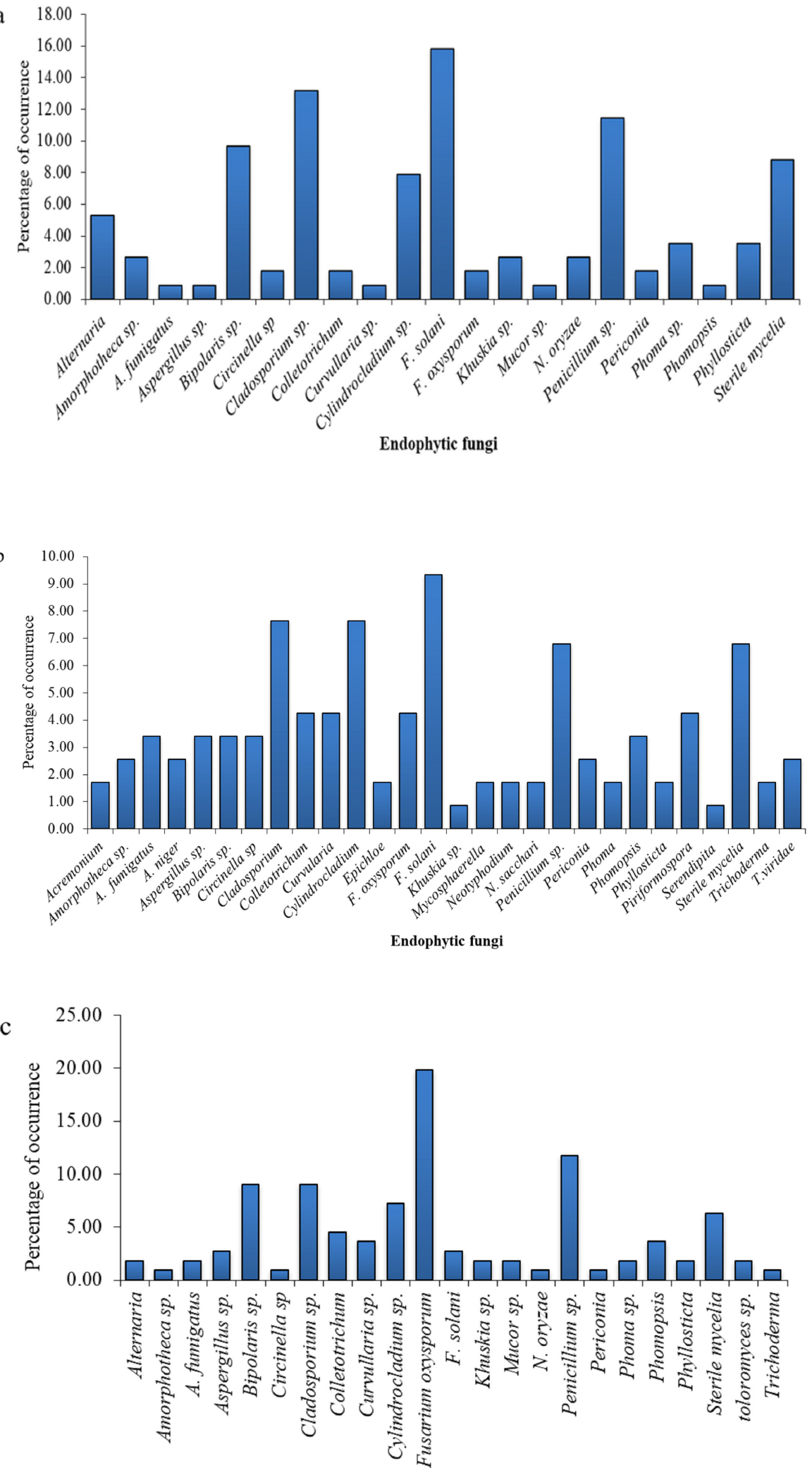

Endophtic fungi

Figure 3. The percentage of dominant $(D)$ isolated endophytic fungi from different locations: a, Baba Budangiri; b, Lakkavalli; and c, Mullayanagiri. 
(Fig. 3c). Our findings are in accordance with previous report in 2017, where fungal isolates like F. oxysporum, Pestalotiopsis spp., Macrophomina spp., Cladosporium spp., and Phomopsisi were isolated from $O$. majorana L. and $F$. oxysporum being the frequently isolated fungi [53]. Eighteen endophytic fungal species were found to be associated with five medicinal plants of Western Ghats, with Curvularia clavata being the dominant fungi [33]. Chaetomium globosum, A. niger, Fusarium spp., and Penicillium spp. were found to be some of the frequently isolated fungi from seven medicinal herbs in the Western Ghats [54].

\subsection{Relative Density (RD) of Endophytic Fungi in Three Sample Sites of Bhadra Wildlife Sanctuary}

The RD of fungal isolates varied within different parts of the host plant. Leaf fragments collected from the Baba Budangiri region had the highest RD of $42 \%$, followed by the Mullayanagiri region $(36 \%)$. Root segments showed the least fungal communities from all three areas suggesting that the endophytes have a preference for leaf colonization (Fig. 4). Similar results of higher colonization rates in the leaves than in root, stem, and petiole were reported in 2016 [24]. Cladosporium cladosporioides, Drechslera sp., and Colletotrichum were some of the frequently isolated fungi from $C$. citrtus, and leaf samples contained more endophyte [37].

\subsection{Relative Percentage of Occurrence (RPO\%) for Different Genera of Endophytic Fungi}

The endophytic fungi of different genera isolated from three sample sites followed a similar pattern of occurrence. Hyphomycetes were the commonly occurring genera with $81.08 \%, 72.88 \%$, and $61.4 \%$ from Lakkavalli, Baba Budangiri, and Mullayanagiri regions, respectively (Fig. 5). These findings support earlier reports on endophytic fungi isolated from shrubby medicinal plants in the Malnad region of Bhadra Wildlife Sanctuary with the highest colonization rates of Hyphomycetes $(28.0 \%)$, Coelomycetes (26\%), and Ascomycota (8.6\%) [55]. Nalini et al. [53], reported 1,529 isolates obtained from 7 medicinal plants of Western Ghats, and colonization was seen more in stem $(80.37 \%)$ than in other plant parts analyzed. Maximum isolates belonged to genera

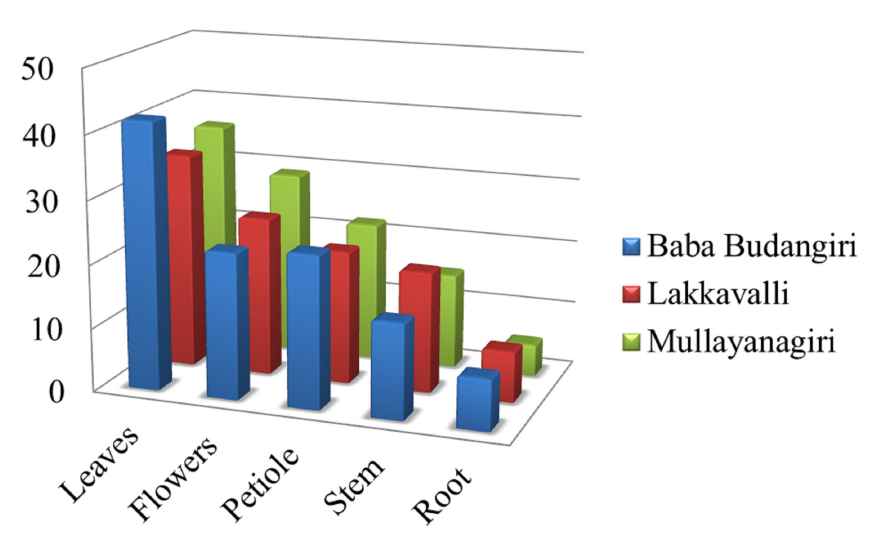

Figure 4. Relative isolations of fungal endophytes from different plant parts of aromatic plants collected from Baba Budangiri, Mullayanagiri, and Lakkavalli.
Coelomycetes (65\%) [54]. Another work in 2016 reported RPO of Hyphomycetes (50\%) to be maximum, followed by Coelomycetes $(33.3 \%)$ and ascomycetes $(8.3 \%)$ for endophytic fungi isolated from Adenium obesum [56].

\subsection{Host Specificity of Endophytic Fungi}

In Lakkavalli region, endophytic fungus like Cylindrocladium was found to be associated with seven plant samples mostly belonging to family Lamiaceae, thereby exhibiting a wide host range, whereas species like Epichloe sp., Khuskia sp., Nigropora sacchari, Periconia, Phomopsis sp., and Phyllosticta sp. were restricted to single host plants. In Mullayanagiri, $F$. oxysporum was isolated from nine different host plants, whereas Trichoderma sp. and Nigrospora oryzae were associated only with $O$. basilicum. Similarly, in the Baba Budangiri region, P. chrysogenum was associated with six host plants belonging to the Lamiaceae family. Mucor sp. and Periconia sp. were seen only in T. vulgaris and $R$. officinali, respectively. Thus, it can be concluded that endophytic fungi may occur more commonly in the host plants belonging to the same family. Likewise, host specificity was exhibited by A. fumigatus, which was found to be associated with C. citretus collected from all the three sample sites. Similarly, Cylindrocladium sp., F. solani, and Curvullaria sp. were isolated from $O$. basilicum, O. majorana, and $R$. graveolens, respectively, collected from all the three regions of Bhadra Wildlife Sanctuary.

\subsection{Diversity Indices}

The Shannon-Wiener index indicated that Baba Budangiri region had a higher index value of 3.19. Simpson's $D$ depicts that Lakkavalli region had higher species diversity with an index value of 0.95. Baba Budangiri and Mullayanagiri regions have similar Simpson's $D$ of 0.91 . These results are also supported by Gini Simpson's diversity index indicating that plants collected from the Lakkavalli region showed greater fungal diversity when compared to the other two regions. The $E$ and species richness were also compared between different regions and it was found that Lakkavalli region had comparatively higher $E(0.72)$ and species richness (5.87) (Table 4).

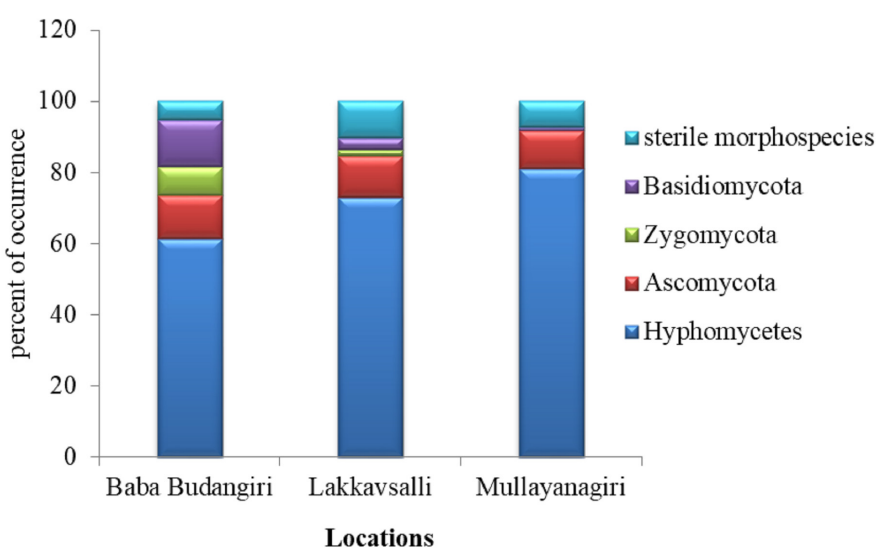

Figure 5. RPO $\%$ of different groups of endophytic fungi from different locations of Bhadra Wildlife Sanctuary. 
Table 4. Diversity indices of endophytic fungi isolated from different regions of Bhadra Wildlife Sanctuary.

\begin{tabular}{lccc}
\multicolumn{1}{c}{ Indices } & Location \\
Lakkavalli & Mullayanagiri \\
Simpson's diversity index & 0.91 & 0.95 & 0.91 \\
Evenness & 0.49 & 0.72 & 0.47 \\
Richness & 4.43 & 5.87 & 4.88 \\
Shannon-Wiener Index (H) & 3.19 & 2.76 & 2.70 \\
Gini Simpson index & 0.09 & 0.05 & 0.09 \\
\hline
\end{tabular}

Table 5. Antibacterial activity of endophytic fungi isolated from selected aromatic plants of Bhadra Wildlife Sanctuary.

\begin{tabular}{|c|c|c|c|c|c|c|}
\hline \multirow{2}{*}{ Locations } & \multirow{2}{*}{ Fungal isolates } & \multicolumn{5}{|c|}{ Zone of inhibition in $\mathrm{mm}$} \\
\hline & & B. subtilis & P. aeruginosa & S. aureus & K. pneumoniae & E. coli \\
\hline \multirow[t]{7}{*}{ Baba Budangiri } & Curvullaria sp. & $16 \pm 0.1$ & $13.3 \pm 1.3$ & $11.9 \pm 1.2$ & $11.5 \pm 1.22$ & $1.21 \pm 0.12$ \\
\hline & Penecillium sp. & $17 \pm 0.2$ & $14.4 \pm 0.3$ & $12.8 \pm 0.98$ & $1.80 \pm 1.27$ & $1.1 \pm 0.24$ \\
\hline & Aspergillus sp. & $18 \pm 1$ & $13.6 \pm 0.8$ & $12 \pm 1.40$ & $1.74 \pm 1.38$ & $1.3 \pm 90.12$ \\
\hline & Curvularia lunata & $11.6 \pm 1.5$ & $12.9 \pm 0.6$ & $2.08 \pm 0.6$ & $1.25 \pm 0.88$ & $0.74 \pm 0.18$ \\
\hline & Colletotrichum sp. & $9.6 \pm 0.2$ & $12.9 \pm 0.1$ & $2.37 \pm 0.2$ & $1.06 \pm 0.81$ & $0.49 \pm 0.23$ \\
\hline & Chaetomium sp. & $15.3 \pm 1.5$ & $11.8 \pm 1.5$ & $1.56 \pm 0.1$ & $10.5 \pm 0.4$ & $0.24 \pm 0.15$ \\
\hline & C. lunata & $13.3 \pm 0.2$ & $11.74 \pm 0.9$ & $1.27 \pm 0.33$ & $0.58 \pm 0.28$ & $0.3 \pm 0.09$ \\
\hline \multirow[t]{10}{*}{ Lakkavalli } & Bipolaris sp. & $12.3 \pm 1.5$ & $11.25 \pm 0.6$ & $0.90 \pm 0.5$ & $0.42 \pm 0.1$ & $0.22 \pm 0.07$ \\
\hline & Rhizopus oryzae & $2.33 \pm 1.3$ & $11.25 \pm 0.6$ & $0.9 \pm 0.2$ & $0.42 \pm 0.1$ & $0.22 \pm 0.07$ \\
\hline & Talaromyces sp. & $20 \pm 0.3$ & $14 \pm 0.93$ & $13.3 \pm 0.3$ & $19.4 \pm 1.1$ & $12.6 \pm 0.32$ \\
\hline & Curvularia sp. & $12 \pm 1.5$ & $14.1 \pm 0.9$ & $2.58 \pm 1.1$ & $11.89 \pm 1.4$ & $12 \pm 0.1$ \\
\hline & F. oxysporum & $18.6 \pm 1.3$ & $14.1 \pm 0.9$ & $2.58 \pm 1.2$ & $1.89 \pm 1.4$ & $1.34 \pm 0.18$ \\
\hline & Chaetomium globosum & $22 \pm 0.65$ & $14.3 \pm 0.2$ & $3.15 \pm 0.5$ & $1.53 \pm 1.12$ & $22 \pm 0.3$ \\
\hline & Piriformospora sp. & $20 \pm 0.2$ & $14.9 \pm 0.2$ & $3 \pm 0.46$ & $2.25 \pm 1.64$ & $11.5 \pm 0.2$ \\
\hline & Alternaria sp. & $17.33 \pm 1$ & $2.85 \pm 5.34$ & $3.72 \pm 0.7$ & $1.89 \pm 1.36$ & $0.97 \pm 0.3$ \\
\hline & Curvularia sp. & $17 \pm 1.36$ & $15.5 \pm 0.1$ & $4.66 \pm 0.3$ & $1.8 \pm 1.5$ & $10.9 \pm 0.9$ \\
\hline & Penicillium sp. & $12.3 \pm 0.5$ & $13.6 \pm 0.76$ & $2.9 \pm 0.4$ & $\begin{array}{c}1.35 \pm 11 \\
0.6 \pm 0.2\end{array}$ & $\begin{array}{c}1.35 \pm 11 \\
0.6 \pm 0\end{array}$ \\
\hline \multirow[t]{5}{*}{ Mullayanagiri } & Alternaria sp. & $19 \pm 0.2$ & $14.47 \pm 0.3$ & $2.99 \pm 1.1$ & $1.98 \pm 1.42$ & $1.28 \pm 0.24$ \\
\hline & Penicillium sp. & $21 \pm 2.6$ & $15.2 \pm 0.6$ & $3.66 \pm 1.1$ & $2.24 \pm 1.57$ & $1.34 \pm 0.31$ \\
\hline & Phyllosticta sp. & $13.6 \pm 0.2$ & $3.62 \pm 0.2$ & $2.67 \pm 0.6$ & $1.48 \pm 1.04$ & $0.81 \pm 0.24$ \\
\hline & Curvularia sp. & $12 \pm 0.2$ & $4.64 \pm 0.3$ & $3.7 \pm 1.2$ & $2.07 \pm 1.4$ & $1.37 \pm 0.24$ \\
\hline & Alternaria sp. & $18.3 \pm 2.1$ & $4.1 \pm 0.80$ & $3.0 \pm 1.08$ & $1.93 \pm 1.3$ & $11.21 \pm 0.2$ \\
\hline
\end{tabular}

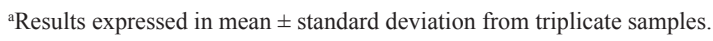

\subsection{Jaccard's Similarity Index (JI)}

The range of similarity between endophytes associated with the three regions of Bhadra Wildlife Sanctuary was computed using a JI. The highest overlap ( $\mathrm{JI}=0.38$ ) was observed for the fungal communities from Lakkavalli and Mullayangiri, followed by Baba Budangiri and Mullayangiri $(\mathrm{JI}=0.34)$, and Baba Budangiri and Lakkavalli showed the least of similarities (0.33). The overlap between all the three regions was found to be 0.24 . These results indicate that the distribution of endophytic fungi in the three sample sites of Bhadra Wildlife Sanctuary is similar and range toward even distribution.

\subsection{Antibacterial Activity of Endophytic Fungi}

A total of 343 endophytic fungi were screened for antibacterial activity against five human pathogenic bacteria. Among the 343, about $312(91 \%)$ isolates exhibited antimicrobial activity against one or more bacteria in which $45 \%$ of the isolates were from the Lakkavalli region, and 23\% from Mullayanagiri and Baba Budangiri region each. Twenty-four isolates (7\%) showed potential activity against all the pathogens tested (Table 5). Chaetomium globosum (PAL3) isolated from the leaf of P. amboinicus collected from the Lakkavalli region exhibited maximum activity with the inhibition zone of $22 \mathrm{~mm}$ against E. coli and B. subtilis. Similar work was reported in 2019 in which A. flavus, an endophytic fungi isolated from $P$. amboinicus, inhibited $E$. coli and $S$. aureus with zone of inhibition of $24.91 \mathrm{~mm}$ [57]. Similarly, the endophytic fungi $A$. terreus isolated from leaves of $T$. vulgaris showed the highest antibacterial activity against $E$. coli and $S$. aureus [57].

\subsection{Antifungal Activity of Endophytic Fungi}

The antifungal activity of the fungal isolates was evaluated for the antagonistic property. A total of 160 endophytic fungi (46.6\%) 
Table 6. Antifungal activity of endophytic fungi against phytopathogens.

\begin{tabular}{|c|c|c|c|c|}
\hline \multirow{2}{*}{ Locations } & \multirow{2}{*}{ Fungal isolates } & \multicolumn{3}{|c|}{ Growth inhibition in percentage } \\
\hline & & A. alternaria & F. oxysporum & A. niger \\
\hline \multirow[t]{9}{*}{ Baba Budangiri } & Alternaria sp. & $36.5 \pm 1.7$ & $45.2 \pm 0.5$ & $43.4 \pm 1.3$ \\
\hline & Penicillium sp. & $17.3 \pm 1.3$ & $5.2 \pm 0.8$ & $32.9 \pm 0.3$ \\
\hline & Curvularia sp. & $22.5 \pm 1.1$ & $55.8 \pm 0.8$ & $22.8 \pm 0.8$ \\
\hline & Piriformospora sp. & $21.9 \pm 1.6$ & $41.9 \pm 0.6$ & $41.7 \pm 0.8$ \\
\hline & F. oxysporum & $20.6 \pm 0.7$ & $32.7 \pm 0.2$ & $19.0 \pm 0.6$ \\
\hline & Phyllosticta sp. & $46.5 \pm 1$ & $41.8 \pm 0.6$ & $34.3 \pm 0.3$ \\
\hline & Cylindrocladium sp. & $16.6 \pm 1.8$ & $52.5 \pm 0.5$ & $18.5 \pm 0.5$ \\
\hline & A. fumigatus & $36.0 \pm 1.6$ & $74.5 \pm 0.2$ & $17.4 \pm 1.2$ \\
\hline & Penicillium sp. & $35.2 \pm 2.3$ & $67.0 \pm 1$ & $16.1 \pm 1.7$ \\
\hline \multirow[t]{8}{*}{ Lakkavalli } & Penicillium sp. & $25.1 \pm 2.5$ & $15.8 \pm 0.4$ & $16.5 \pm 0.9$ \\
\hline & Phyllosticta & $60.5 \pm 0.9$ & $68.4 \pm 0.8$ & $24.9 \pm 0.6$ \\
\hline & Toloromyces sp. & $41.8 \pm 1.8$ & $26.0 \pm 0.9$ & $20.0 \pm 1.1$ \\
\hline & C. globosum & $73.7 \pm 1.7$ & $74.5 \pm 0.9$ & $19.0 \pm 0.3$ \\
\hline & Phomopsis sp. & $35.4 \pm 1.2$ & $55.5 \pm 1.2$ & $35.3 \pm 0.5$ \\
\hline & Curvularia sp. & $67.2 \pm 0.8$ & $46.4 \pm 0.3$ & $18.3 \pm 1$ \\
\hline & A. niger & $43.0 \pm 0.9$ & $23.8 \pm 0.3$ & $19.4 \pm 0.2$ \\
\hline & Chaetomium sp. & $37.4 \pm 0.6$ & $22.7 \pm 0.6$ & $15.4 \pm 0.7$ \\
\hline \multirow[t]{7}{*}{ Mullayanagiri } & F. oxysporum & $78.0 \pm 0.8$ & $74.9 \pm 0.2$ & $43.8 \pm 0.4$ \\
\hline & Phomopsis sp. & $35.8 \pm 1.1$ & $21.7 \pm 1.1$ & $34.6 \pm 0.3$ \\
\hline & Colletotrichum sp. & $42.2 \pm 0.8$ & $35.5 \pm 0.4$ & $19.5 \pm 1$ \\
\hline & Alternaria sp. & $54.0 \pm 1.3$ & $27.4 \pm 0.8$ & $16.9 \pm 1.2$ \\
\hline & N. oryzae & $67.3 \pm 0.6$ & $55.6 \pm 0.9$ & $53.7 \pm 1.8$ \\
\hline & Rhizopus oryzae & $25.1 \pm 1.7$ & $45.5 \pm 0.2$ & $15.8 \pm 0.4$ \\
\hline & C. lunata & $45.8 \pm 0.2$ & $63.9 \pm 0.6$ & $24.3 \pm 1.3$ \\
\hline
\end{tabular}

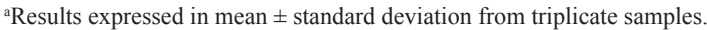

were found active against one or more test pathogens. More than $15 \%$ inhibition in radial growth against all the tested pathogens was recorded in $27(7.8 \%)$ isolates (Table 6). The most notable inhibition was demonstrated by $C$. globosum (PAL3) from Lakkavalli against $F$. oxysporum, giving $74.5 \%$ inhibition in radial growth. Similar work was reported in which, 24 isolates among the 72 endophytic fungi from Cedrus deodara, Pinus roxburgii, and Abies pindrow inhibited 3 or more phytopathogens by at least $50 \%$ in dual culture [22].

\section{CONCLUSION}

India has many unique ecological niches harboring varieties of plants. One such region is situated in the Western Ghats, India, which contains diversified plants, animals, and microorganisms. This present study reveals the composition and variability of fungal endophytes associated with 11 aromatic plants from 3 different regions of Bhadra Wildlife Sanctuary, Western Ghats, Karnataka. A total of 343 endophytic fungi were isolated from Baba Budangiri, Lakkavalli, and Mullayanagiri regions. $P$. amboinicus showed better association with endophytic fungi from all the regions with the highest CF and IR, whereas $Z$. officinale demonstrated the least fungal association among the selected plant samples. Host specificity was observed for specific endophytes like C. globosum, which was associated with $C$. citretus from all the three sample sites. Diversity indices were measured by Shannon-Weiner, Simpson's diversity and Gini Simpson's diversity index, and high diversity indices were noted for the Lakkavalli region, followed by Mullayanagiri and Baba Budangiri regions. JI was used to assess the similarity of fungal species from the three sample sites. Lakkavalli and Mullayangiri $(\mathrm{JI}=0.38)$ showed the highest fungal overlap. All the isolates were subjected to antimicrobial activity against pathogenic bacteria and fungi. $91 \%$ and $46.6 \%$ of the isolates showed antibacterial and antifungal activity, respectively, against one or more tested pathogens. Chaetomium globosum from the Lakkavalli region was the most potential isolate that can be further exploited for the production of bioactive compounds.

\section{ACKNOWLEDGMENTS}

This work has been funded by the department of backward classes' government of Karnataka for providing Ph.D-OBC fellowship. The authors thank the Department of Microbiology and Biotechnology, Bangalore University, Bangalore, for providing the facility needed in carrying out this research work. 


\section{AUTHOR CONTRIBUTIONS}

All authors made substantial contributions to conception and design, acquisition of data, or analysis and interpretation of data; took part in drafting the article or revising it critically for important intellectual content; agreed to submit to the current journal; gave final approval of the version to be published; and agree to be accountable for all aspects of the work. All the authors are eligible to be an author as per the international committee of medical journal editors (ICMJE) requirements/guidelines.

\section{CONFLICTS OF INTEREST}

The authors report no financial or any other conflicts of interest in this work.

\section{ETHICAL APPROVALS}

Not applicable.

\section{REFERENCES}

1. Shoji JY, Arioka M, Kitamoto K. Possible involvement of pleiomorphic vacuolar networks in nutrient recycling in filamentous fungi. Autophagy 2006;2(3):226-7.

2. Ioca LP, Allard PM, Berlinck RGS. Thinking big about small beingsthe (yet) underdeveloped microbial natural products chemistry in Brazil. Nat Prod Rep 2014;31(5):646-75.

3. Hardoim PR, Van Overbeek LS, Berg G, Pirttilä AM, Compant S, Campisano A, et al. The hidden world within plants: ecological and evolutionary considerations for defining functioning of microbial endophytes. Microbiol Mol Biol Rev 2015;79(3):293-320.

4. Kumaresan V, Suryanarayanan TS. Occurrence and distribution of endophytic fungi in a mangrove community. Mycol Res 2001;105(11):1388-91.

5. Arnold AE. Endophytic fungi: hidden components of tropical community ecology. Trop For Community Ecol 2008;1:178-88.

6. Mehmood A. Effect of indole-3-acetic acid and flavonoids on association of maize roots and phytostimulant endophytic fungi. Doctoral dissertation, Abdul Wali Khan University, Mardan, 2019.

7. Aly AH, Debbab A, Kjer J, Proksch P. Fungal endophytes from higher plants: a prolific source of phytochemicals and other bioactive natural products. Fungal Divers 2010;41(1):1-6.

8. Zhao J, Zhou L, Wang J, Shan T, Zhong L, Liu X, et al. Endophytic fungi for producing bioactive compounds originally from their host plants. Curr Res, Technol Educ Trop Appl Microbiol Microbial Biotechnol 2010;1:567-76.

9. Johnson LJ, de Bonth AC, Briggs LR, Caradus JR, Finch SC, Fleetwood DJ, et al. The exploitation of epichloae endophytes for agricultural benefit. Fungal Divers 2013;60(1):171-88.

10. van der Heijden MG, Martin FM, Selosse MA, Sanders IR. Mycorrhizal ecology and evolution: the past, the present, and the future. New Phytol 2015;205(4):1406-23.

11. Jia M, Chen L, Xin HL, Zheng CJ, Rahman K, Han T, et al. A friendly relationship between endophytic fungi and medicinal plants: a systematic review. Front Microbiol 2016;7:906.

12. Rao RR, Sagar K, Syamasundar KV. Wild aromatic plant species of western ghats: diversity, conservation and utilization. International Seminar on Multidisciplinary Approaches in Angiosperm Systematics, pp 358-71, 2006.

13. Raju R, Heggde SN. Bhadra wildlife sanctuary-a fragile ecosystem. Indian Forester 1995;121(10):938-48.
14. Krishnaswamy J, Kiran MC, Ganeshaiah KN. Tree model based eco-climatic vegetation classification and fuzzy mapping in diverse tropical deciduous ecosystems using multi-season NDVI. Int J Remote Sens 2004;25(6): 1185-205.

15. Mamadalieva NZ, Akramov DK, Ovidi E, Tiezzi A, Nahar L, Azimova SS, et al. Aromatic medicinal plants of the Lamiaceae family from Uzbekistan: ethnopharmacology, essential oils composition, and biological activities. Medicines (Basel) 2017;4(1):8.

16. Bown D. The Royal Horticultural Society encyclopedia of herbs \& their uses. Dorling Kindersley Limited, London, UK, 1995.

17. Busatta C, Vidal RS, Popiolski AS, Mossi AJ, Dariva C, Rodrigues MR, et al. Application of Origanum majorana L. essential oil as an antimicrobial agent in sausage. Food Microbiol 2008;25(1):207-11.

18. Ebadollahi A, Ziaee M, Palla F. Essential oils extracted from different species of the lamiaceae plant family as prospective bioagents against several detrimental pests. Molecules 2020;25(7):1556.

19. Prathap G. India's share of world research according to Science and Engineering Indicators 2016. Curr Sci 2016;110(12):2210.

20. Harisha MN, Hosetti BB. Diversity and distribution of avifauna of Lakkavalli range forest, Bhadra wildlife sanctuary, Western Ghat, India. Ecoprint Int J Ecol 2009;16:21-7.

21. Nanda A, Suresh HS, Krishnamurthy YL. Phenology of a tropical dry deciduous forest of Bhadra wildlife sanctuary, southern India. Ecol Processes 2014;3(1):1.

22. Qadri M, Johri S, Shah BA, Khajuria A, Sidiq T, Lattoo SK, et al. Identification and bioactive potential of endophytic fungi isolated from selected plants of the Western Himalayas. SpringerPlus 2013;2(1):8.

23. Radu S, Kqueen CY. Preliminary screening of endophytic fungi from medicinal plants in Malaysia for antimicrobial and antitumor activity. Malays J Med Sci 2002;9(2):23.

24. Barnett HL, Hunter BB. Illustrated genera of imperfect fungi. 4th edition, APS Press, St. Paul, MN, p 218, 1998.

25. Goveas SW, Madtha R, Nivas SK, D'Souza L. Isolation of endophytic fungi from Coscinium fenestratum-a red listed endangered medicinal plant. EurAsian J BioSci 2011;5:48-53.

26. Govinda Rajulu MB, Thirunavukkarasu N, Babu AG, Aggarwal A, Suryanarayanan TS, Reddy MS. Endophytic Xylariaceae from the forests of Western Ghats, southern India: distribution and biological activities. Mycology 2013;4(1):29-37.

27. Li P, Wu Z, Liu T, Wang Y. Biodiversity, phylogeny, and antifungal functions of endophytic fungi associated with Zanthoxylum bungeanum. Int J Mol Sci 2016;17(9):1541.

28. Lakshman HC, kurandawad JM. Diversity of the endophytic fungi isolated from Spilanthes acmella linn.-a promising medicinal plant. Int J Pharm Biosci 2013;4(2):1259-66.

29. Zhou J, Diao X, Wang T, Chen G, Lin Q, Yang X, et al. Phylogenetic diversity and antioxidant activities of culturable fungal endophytes associated with the mangrove species Rhizophora stylosa and $R$. mucronata in the South China Sea. PLoS One 2018;13(6):e0197359.

30. Caso C, Angeles gil M. The Gini-Simpson index of diversity: estimation in the stratified sampling. Commun Stat Theory Methods 1988;17(9):2981-95.

31. Raviraja NS. Fungal endophytes in five medicinal plant species from Kudremukh Range, Western Ghats of India. J Basic Microbiol 2005;45(3):230-5.

32. Kannan KP, Thilakavathi R, Madhan KD. Biodiversity of endophytic fungi from Mukia maderespatana (L) M. Roem-a first report. J Bacteriol Mycol Open Access 2017;4(4):109-13.

33. Caceres A, Cabrera O, Morales O, Mollinedo P, Mendia P. Pharmacological properties of Moringa oleifera. 1: preliminary screening for antimicrobial activity. J Ethnopharmacol 1991; 33(3):213-6.

34. Korolik V, Ottemann KM. Two spatial chemotaxis assays: the nutrient-depleted chemotaxis assay and the agarose-plug-bridge assay in bacterial chemosensing. Humana Press, New York, NY, pp 23-31, 2018. 
35. Hosseyni-Moghaddam MS, Soltani J. Bioactivity of endophytic Trichoderma fungal species from the plant family Cupressaceae. Ann Microbiol 2014;64(2):753-61.

36. Koba K, Sanda K, Guyon C, Raynaud C, Chaumont JP, Nicod L. In vitro cytotoxic activity of Cymbopogon citratus L. and Cymbopogon nardus L. essential oils from Togo. Bangladesh J Pharmacol 2009;4(1):29-34.

37. Al-Snafi AE. Nutritional value and pharmacological importance of citrus species grown in Iraq. IOSR J Pharm 2016;6(8):76-108.

38. Bertuzzi G, Tirillini B, Angelini P, Venanzoni R. Antioxidative action of citrus limonum essential oil on skin. Eur J Med Plants 2012; 3(1): $1-9$.

39. Chaudhari SY, Ruknuddin G, Prajapati P. Ethno medicinal values of Citrus genus: a review. Med J DY Patil Vidyapeeth 2016;9(5):560.

40. Ram D, Ram M, Singh R. Optimization of water and nitrogen application to menthol mint (Mentha arvensis L.) through sugarcane trash mulch in a sandy loam soil of semi-arid subtropical climate. Bioresour Technol 2006;97(7):886-93.

41. Kumar A, Shukla R, Singh P, Singh AK, Dubey NK. Use of essential oil from Mentha arvensis L. to control storage moulds and insects in stored chickpea. J Sci Food Agric 2009;89(15):2643-9.

42. Javanmardi J, Khalighi A, Kashi A, Bais HP, Vivanco JM. Chemical characterization of basil (Ocimum basilicum L.) found in local accessions and used in traditional medicines in Iran. J Agric Food Chem 2002;50(21):5878-83.

43. Upadhyay RK. Tulsi:a holy plant with high medicinal and therapeutic value. Int J Green Pharm 2017;11(01):S1-12.

44. Jun WJ, Han BK, Yu KW, Kim MS, Chang IS, Kim HY, et al. Antioxidant effects of Origanum majorana L. on superoxide anion radicals. Food Chem 2001;75(4):439-44.

45. Bouyahya A, Chamkhi I, Benali T, Guaouguaou FE, Balahbib A, El Omari N, et al. Traditional use, phytochemistry, toxicology, and pharmacology of Origanum majorana L. J Ethnopharmacol 2020;265:113318.

46. Sreejith G, Jayasree M, Latha PG, Suja SR, Shyamal S, Shine VJ, et al. Hepatoprotective activity of Oxalis corniculata L. ethanolic extract against paracetamol induced hepatotoxicity in Wistar rats and its in vitro antioxidant effects. Indian J Exp Biol 2014;52(2):147-52.

47. Arumugam G, Swamy MK, Sinniah UR. Plectranthus amboinicus (Lour.) Spreng: botanical, phytochemical, pharmacological and nutritional significance. Molecules 2016;21(4):369.

48. Barreto HM, Silva Filho EC, Lima ED, Coutinho HD, Morais-Braga MF, Tavares CC, et al. Chemical composition and possible use as adjuvant of the antibiotic therapy of the essential oil of Rosmarinus officinalis L. Ind Crops Prod 2014;59:290-4.

49. Parkash V, Aggarwal A, Sharma V. Rhizospheric effect of vesiculararbuscular mycorrhizal inoculation on biomass production of Ruta graveolens L.: a potential medicinal and aromatic herb. J Plant Nutr 2011;34(9):1386-96.

50. Ali BH, Blunden G, Tanira MO, Nemmar A. Some phytochemical, pharmacological and toxicological properties of ginger (Zingiber officinale Roscoe): a review of recent research. Food Chem Toxicol 2008;46(2):409-20.

51. Akram M, Shah MI, Usmanghan K, Mohiuddin E, Sami A, Asif $\mathrm{M}$, et al. Zingiber officinale roscoe (a medicinal plant). Pak J Nutr 2011;10(4):399-400

52. Sharmila T, Sreelatha GL, Geethanjali P, Subramanya S. Antibacteria activities of endophytic fungal strains isolated from aromatic plants. Asian J Pharm Sci Technol 2017;7:28-33.

53. Nalini MS, Sunayana N, Prakash HS. Endophytic fungal diversity in medicinal plants of Western Ghats, India. Int $\mathrm{J}$ Biodivers 2014;2014:1-9.

54. Campos RP, Jacob JK, Ramos HC, Temanel FB. Mycopharmacological properties of endophytic fungi isolated from Cuban Oregano (Plectranthus amboinicus Lour.) leaves. Asian J Biol Life Sci 2019;8(3):103.

55. Naik BS, Krishnappa M, Krishnamurthy YL. Biodiversity of endophytic fungi from seven herbaceous medicinal plants of Malnad region, Western Ghats, southern India. J For Res 2014;25(3):707-11.

56. Krishnamurthy YL, Naik SB, Jayaram S. Fungal communities in herbaceous medicinal plants from the Malnad region, Southern India. Microbes Environ 2008;23(1):24-8.

57. Sayed MA, Ali EA, Ahmed AA, Hamed MR. Antimicrobial activity of Thymus vulgaris L. and associated endophytes extracts. Egypt J Exp Biol 2020;16(2):141-7.

How to cite this article:

Jagadish R, Chowdappa S. Diversity and antimicrobial potential of endophytic fungi from aromatic plants of Bhadra Wildlife Sanctuary, Western Ghats, Karnataka. J Appl Biol Biotechnol 2021; 9(05):1-12. 